Article

\title{
Focal Areas for Measuring the Human Well-Being Impacts of a Conservation Initiative
}

\author{
Craig Leisher ${ }^{1, *}$, Leah H. Samberg ${ }^{2}$, Pieter van Beukering ${ }^{3}$ and M. Sanjayan ${ }^{1}$ \\ 1 Central Science, The Nature Conservatory, 4245 N. Fairfax Drive, Arlington, VA 22203, USA; \\ E-Mail: msanjayan@tnc.org \\ 2 Consultant, 2312 Skyline Drive, Missoula, MT 59802, USA; E-Mail: 1samberg@gmail.com \\ 3 Department of Environmental Economics, Institute for Environmental Studies, VU University, de \\ Boelelann 1105, Amsterdam, The Netherlands; E-Mail: pieter.van.beukering@ivm.vu.nl \\ * Author to whom correspondence should be addressed; E-Mail: cleisher@tnc.org; \\ Tel.: +1-973-379-4847; Fax: +1-703-841-1283.
}

Received: 31 December 2012; in revised form: 8 February 2013 / Accepted: 16 February 2013 / Published: 6 March 2013

\begin{abstract}
Within conservation, the need to measure the impacts on people from conservation initiatives such as projects and programs is growing, but understanding and measuring the multidimensional impacts on human well-being from conservation initiatives is complex. To understand the constituent components of human well-being and identify which components of well-being are most common, we analyzed 31 known indices for measuring human well-being. We found 11 focal areas shared by two or more indices for measuring human well-being, and the focal areas of living standards, health, education, social cohesion, security, environment, and governance were in at least 14 of the 31 human well-being indices. We examined each of the common focal areas and assessed its relevance to measuring the human well-being impacts of a conservation initiative. We then looked for existing indices that include the relevant focal areas and recommend the use of Stiglitz et al. (2009) — a framework designed to measure economic performance and social progress - as a starting place for understanding and selecting human well-being focal areas suitable for measuring the impacts on people from a conservation initiative.
\end{abstract}

Keywords: socio-economic; poverty; measurement; biodiversity; subjective; objective 


\section{Introduction}

As awareness of the tight links between conservation and human livelihoods increases, the missions of many large conservation organizations have shifted. Among others, The Nature Conservancy, World Wildlife Fund, Conservation International, BirdLife International, and Fauna and Flora International now make explicit reference to people in their mission or vision statements. Yet policies and procedures determining how conservation organizations measure and ultimately manage impacts on people are only just developing. This period of development is especially critical because what conservation organizations choose to measure is what they end up defining as success.

Measuring the impacts on people from a biodiversity conservation initiative such as a project or program can help identify who gains and who loses, confirm or dispel a hypothesized impact pathway, and potentially increase the benefits to people from conservation. It could help conservation with the ethical imperative to do no harm to people - an imperative that conservation and conservation organizations have not always successfully met e.g., [1,2]. Conservation also has a practical imperative to measure impacts on people. Without measurements of impacts, comparing the costs and benefits of various conservation strategies is problematic, and conservation investments may be based more on anecdote and experience than empirical evidence [3]. Moreover, conservation is largely peripheral to the current generation of global development goals. Building empirical evidence of how nature's goods and services provide benefits to people could contribute to expanding the constituency for conservation and influencing the next generation of global development goals.

The primary challenge lies in understanding and measuring the multidimensional impacts of nature on people. Feedback loops, direct and indirect human impacts, and underlying drivers like climate change create complex and interdependent relationships between people and nature. Within the conservation sector, robust ways to measure ecological impacts have been developed e.g., [4,5]. Yet there is no equivalent level of rigor in measuring impacts on people, though there are nascent efforts e.g., [6,7].

Consensus positions among large conservation organizations have emerged in recent years on standards for the practice of conservation (12 conservation organizations) [8], conservation and human rights (8 conservation organizations) [9], and conservation-poverty links where a recent survey found that most conservation professionals share a view that conservation and poverty as linked [10]. However, this has not yet happened for measuring human well-being (HWB). This may be because there are numerous frameworks for measuring HWB, and within these frameworks, diverse topics or focal areas that advocates believe are important for measuring HWB. Examples of HWB frameworks include Bhutan's Gross National Happiness Index and the United Nation Development Programme's Human Development Index, and examples of focal areas include health and education. A review of existing HWB frameworks and focal areas to identify which are relevant to conservation has not yet been done.

How HWB is defined determines what is measured, and the conceptualization of HWB can be characterized as diverse, hence the numerous HWB frameworks, which we term "indices" for convenience. Here, we examine the constituent focal areas of 31 existing HWB indices to ascertain if there are particular focal areas that predominate and answer the research questions: (i) what are the most common focal areas for measuring HWB; and (ii) which of these focal areas are relevant to 
measuring HWB in a conservation initiative? We then review existing indices to identify those potentially suitable for conservation.

\section{Methods}

We chose "focal areas" as the unit of analysis rather than the higher level of "dimensions" included in some indices e.g., $[11,12]$, as it is focal areas that drive the selection of indicators. Here we define focal areas as the aspects or attributes of life that impact HWB. While "domains" is a more widely used term in the HWB literature, we chose to call them "focal areas" because it is a more selfexplanatory term, but the two are synonymous. We chose not to include specific indicators for each focal area because this allows for selecting indicators relevant to a specific conservation context.

We build on a recent review of 20 HWB indices [13] but eliminate two outliers from this set (Quality of Life Index for Developed Countries, and Well-Being in EU Countries Multidimensional Index of Sustainability) because none of their focal areas are included in any of the other indices reviewed. We then added 13 HWB indices identified by the OECD's Better Life Initiative and catalogued on its resource site [14]. For the $31 \mathrm{HWB}$ indices reviewed, we noted the focal areas of each index as defined by the index's authors (Table 1).

Table 1. Existing human well-being indices reviewed and their focal areas.

\begin{tabular}{|c|c|c|}
\hline $\begin{array}{l}\text { Australian Unity Well-Being Index } \\
\text { Achievements in Life } \\
\text { Business } \\
\text { Community Connectedness } \\
\text { Economic Situation } \\
\text { Future Security } \\
\text { Health } \\
\text { How Australia Is Governed } \\
\text { How Safe You Feel } \\
\text { National Security } \\
\text { Personal Relationships } \\
\text { Social Conditions } \\
\text { Spirituality/Religion } \\
\text { Standard of Living } \\
\text { State of the Environment } \\
\text { Basic Capacities Index } \\
\text { Child Mortality } \\
\text { Education } \\
\text { Maternal Health } \\
\text { Canadian Index of Well-Being } \\
\text { Community Vitality } \\
\text { Democratic Engagement } \\
\text { Education } \\
\text { Environment } \\
\text { Healthy Populations } \\
\text { Leisure and Culture } \\
\text { Time Use } \\
\text { Child and Youth Well-Being Index }\end{array}$ & $\begin{array}{l}\text { Living Standard } \\
\text { Educational Attainments } \\
\text { Emotional/Spiritual Well-Being } \\
\text { Family Economic Well-Being } \\
\text { Health } \\
\text { Place in Community } \\
\text { Safety/Behavioral Concerns } \\
\text { Social Relationships } \\
\text { Commission on the Measurement of } \\
\text { Economic Performance and Social } \\
\text { Progress } \\
\text { Education } \\
\text { Environment } \\
\text { Health } \\
\text { Insecurity, Economic as well as a } \\
\text { Physical } \\
\text { Material Living Standards } \\
\text { Personal Activities including Work } \\
\text { Political Voice and Governance } \\
\text { Social Connections and Relationships } \\
\text { Commitment to Development Index } \\
\text { Aid Quality and Quantity } \\
\text { Migration } \\
\text { Security } \\
\text { Technology } \\
\text { Trade Openness } \\
\text { Economist Intelligence Unit's QoL } \\
\text { Index }\end{array}$ & $\begin{array}{l}\text { Failed State Index } \\
\text { Delegitimization of the State } \\
\text { Demographic Pressures } \\
\text { Refugees/IDPs } \\
\text { Economic Decline } \\
\text { External Intervention } \\
\text { Factionalized Elites } \\
\text { Group Grievance } \\
\text { Human Flight } \\
\text { Human Rights } \\
\text { Public Services } \\
\text { Security Apparatus } \\
\text { Uneven Development } \\
\text { Gallup Healthways Well-Being Index } \\
\text { Basic Access } \\
\text { Emotional Health } \\
\text { Healthy Behavior } \\
\text { Life Evaluation }\end{array}$ \\
\hline
\end{tabular}


Table 1. Cont.

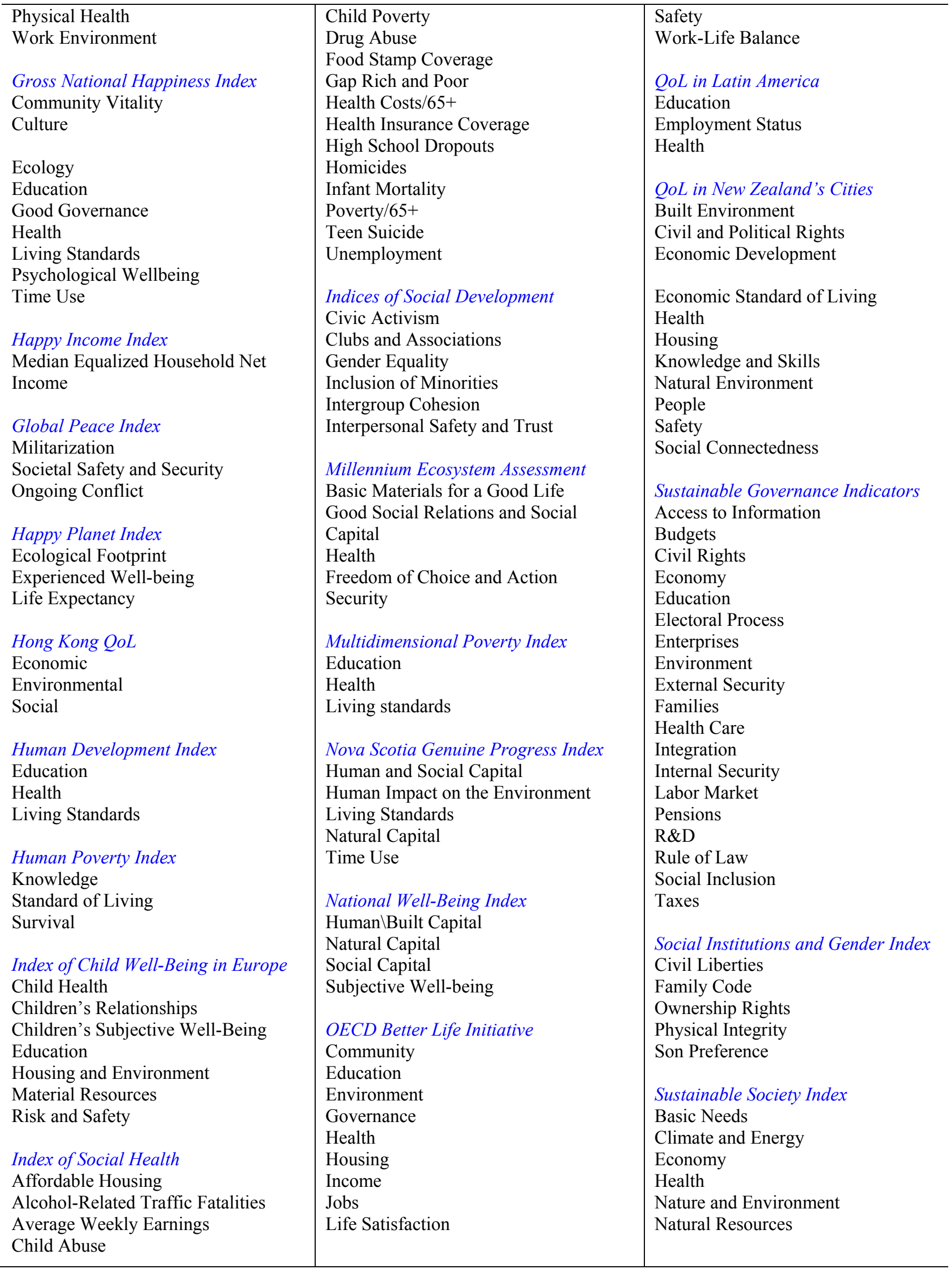


Table 1. Cont.

\begin{tabular}{l|l|l}
\hline Personal and Social Development & Culture & Land Diversity \\
Transition & Domesticated Diversity & Land Quality \\
& Energy and Materials & Local Air Quality \\
National Wealth \\
State of the Commonwealth Index & Freedom and Governance & Gender Equity \\
Communities & Global Atmosphere & Population \\
Economy & Health & Resource Sectors \\
Education & Household Equity & Sea \\
Environment & Household Wealth & Wild Diversity \\
Government & Inland Waters & \\
Kell-Being of Nations & Knowledge & \\
\hline
\end{tabular}

Sources: index-specific webpages (hyperlinked above), Smith et al. [13], and OECD's Progress Around the World [14].

We categorized similar focal areas under a common heading, thus, the index-specific focal areas of income, poverty, wealth, material well-being, economic well-being, and several others were combined under "Living Standards"- the most common focal area for this category in the reviewed indices. Longevity, maternal health, child health, and heath care were combined under the frequently occurring "Health' category. We did the same for "Education" (which included focal areas on knowledge, human capital, educational attainment, and others), "Social Cohesion" (social relationships, community, connectedness, intergroup cohesion, social capital, and others), "Security" (physical security, economic security, political security, human rights, and others), "Environment" (natural environment, human impacts on the environment, natural resource use, air quality, water quality, and others), "Governance" (political voice, freedoms, democratic engagement, civil liberties, electoral process, and others), "Work-Life Balance" (time use, family life, and personal activities including work and others), "Subjective Well-being" (happy life, emotional well-being, psychological well-being, spiritual well-being, and others), and "Equality" (gender equality and household equality). "Culture" included only itself. For focal areas where it was unclear what it comprised, such as "Basic Needs", we looked at the details of the focal area within the index documentation and characterized it based on the indicators the authors chose to measure the focal area. While the element of judgment inherent in such characterizations could be a source of bias, given our purpose of identifying the most common focal areas across the reviewed HWB indices, changes in how the few ambiguous focal areas were characterized would not substantively change the results.

\section{Results and Discussion}

\subsection{Focal Areas for Measuring Human Well-Being}

When 31 indices for measuring HWB are examined, it is clear that a handful of focal areas predominate. We identified a total of 11 focal areas that appear in at least two indices, and these 11 encompass roughly half of the unique focal areas in the 31 indices (Table 2).

If we compare the nine focal areas above with the 441 indicators from 20 HWB indices categorized by focal area in Smith et al. [13], the same top five focal areas arise though in a slightly different order (Table 3). This suggests that the predominant focal areas for HWB are similar whether measured by the number of indices that include a focal area, as we do, or by the number of indicators under various focal areas within the indices, as Smith et al. did [13]. 
Table 2. Ranked list of human well-being focal areas from 31 indices reviewed showing the 11 focal areas that appear in at least two indices.

\begin{tabular}{|c|c|c|c|}
\hline Rank & Focal Area & $\begin{array}{c}\text { \# of Indices with } \\
\text { Focal Area }\end{array}$ & Indices \\
\hline 1 & $\begin{array}{l}\text { Living } \\
\text { Standards }\end{array}$ & 23 & $\begin{array}{l}\text { Australian Unity Well-Being Index; Canadian Index of Well-Being; Child } \\
\text { and Youth Well-Being Index; Commission on the Measurement of } \\
\text { Economic Performance and Social Progress; Economist Intelligence } \\
\text { Unit's QoL Index; Failed State Index; Gross National Happiness; Happy } \\
\text { Income Index; Hong Kong QoL; Human Development Index; Human } \\
\text { Poverty Index; Index of Child Well-Being in Europe; Index of Social } \\
\text { Health; Millennium Ecosystem Assessment; Multidimensional Poverty } \\
\text { Index; Nova Scotia Genuine Progress Index; OECD Better Life Initiative; } \\
\text { QoL in New Zealand's Cities; QoL in Latin America; State of the } \\
\text { Commonwealth Index; Sustainable Governance Indicators; Sustainable } \\
\text { Society Index; Well-Being of Nations }\end{array}$ \\
\hline 2 & Health & 22 & $\begin{array}{l}\text { Australian Unity Well-Being Index; Basic Capacities Index; Canadian } \\
\text { Index of Well-Being; Child and Youth Well-Being Index; Commission on } \\
\text { the Measurement of Economic Performance and Social Progress; } \\
\text { Economist Intelligence Unit's QoL Index; Gallup Healthways Well-Being } \\
\text { Index; Gross National Happiness; Happy Planet Index; Human } \\
\text { Development Index; Human Poverty Index; Index of Child Well-Being in } \\
\text { Europe; Index of Social Health; Millennium Ecosystem Assessment; } \\
\text { Multidimensional Poverty Index; OECD Better Life Initiative; QoL in } \\
\text { New Zealand's Cities; QoL in Latin America; Social Institutions and } \\
\text { Gender Index; Sustainable Governance Indicators; Sustainable Society } \\
\text { Index; Well-Being of Nations }\end{array}$ \\
\hline 3 & Education & 18 & $\begin{array}{l}\text { Basic Capacities Index; Canadian Index of Well-Being; Child and Youth } \\
\text { Well-Being Index; Commission on the Measurement of Economic } \\
\text { Performance and Social Progress; Index of Social Health; Gross National } \\
\text { Happiness; Human Development Index; Human Poverty Index; Index of } \\
\text { Child Well-Being in Europe; Multidimensional Poverty Index; National } \\
\text { Well-Being Index; OECD Better Life Initiative; QoL in New Zealand's } \\
\text { Cities; QoL in Latin America; State of the Commonwealth Index; } \\
\text { Sustainable Governance Indicators; Sustainable Society Index; Well- } \\
\text { Being of Nations }\end{array}$ \\
\hline 4 & $\begin{array}{l}\text { Social } \\
\text { Cohesion }\end{array}$ & 16 & $\begin{array}{l}\text { Australian Unity Well-Being Index; Canadian Index of Well-Being; Child } \\
\text { and Youth Well-Being Index; Commission on the Measurement of } \\
\text { Economic Performance and Social Progress; Economist Intelligence } \\
\text { Unit's QoL Index; Gross National Happiness; Index of Child Well-Being } \\
\text { in Europe; Indices of Social Development; Millennium Ecosystem } \\
\text { Assessment; National Well-Being Index; Nova Scotia Genuine Progress } \\
\text { Index; OECD Better Life Initiative; QoL in New Zealand's Cities; State } \\
\text { of the Commonwealth Index; Sustainable Governance Indicators; } \\
\text { Sustainable Society Index }\end{array}$ \\
\hline
\end{tabular}


Table 2. Cont.

\begin{tabular}{|c|c|c|c|}
\hline Rank & Focal Area & $\begin{array}{l}\text { \# of Indices with } \\
\text { Focal Area }\end{array}$ & Indices \\
\hline 5 & Security & 15 & $\begin{array}{l}\text { Australian Unity Well-Being Index; Child and Youth Well-Being Index; } \\
\text { Commission on the Measurement of Economic Performance and Social } \\
\text { Progress; Commitment to Development Index; Economist Intelligence } \\
\text { Unit's QoL Index; Failed State Index; Global Peace Index; Index of Child } \\
\text { Well-Being in Europe; Index of Social Health; Indices of Social } \\
\text { Development; Millennium Ecosystem Assessment; OECD Better Life } \\
\text { Initiative; QoL in New Zealand's Cities; Sustainable Governance } \\
\text { Indicators; Well-Being of Nations }\end{array}$ \\
\hline 5 & Environment & 15 & $\begin{array}{l}\text { Australian Unity Well-Being Index; Canadian Index of Well-Being; } \\
\text { Commission on the Measurement of Economic Performance and Social } \\
\text { Progress; Commitment to Development Index; Gross National Happiness; } \\
\text { Happy Planet Index; Hong Kong QoL; Index of Child Well-Being in } \\
\text { Europe; National Well-Being Index; Nova Scotia Genuine Progress } \\
\text { Index; OECD Better Life Initiative; QoL in New Zealand's Cities; State } \\
\text { of the Commonwealth Index; Sustainable Society Index; Well-Being } \\
\text { of Nations }\end{array}$ \\
\hline 6 & Governance & 14 & $\begin{array}{l}\text { Australian Unity Well-Being Index; Canadian Index of Well-Being; } \\
\text { Commission on the Measurement of Economic Performance and Social } \\
\text { Progress; Economist Intelligence Unit's QoL Index; Failed State Index; } \\
\text { Gross National Happiness; Indices of Social Development; Millennium } \\
\text { Ecosystem Assessment; OECD Better Life Initiative; QoL in New } \\
\text { Zealand's Cities; State of the Commonwealth Index; Social Institutions } \\
\text { and Gender Index; Sustainable Governance Indicators; Well-Being } \\
\text { of Nations }\end{array}$ \\
\hline 7 & $\begin{array}{l}\text { Work-Life } \\
\text { Balance }\end{array}$ & 8 & $\begin{array}{l}\text { Canadian Index of Well-Being; Commission on the Measurement of } \\
\text { Economic Performance and Social Progress; Gallup Healthways Well- } \\
\text { Being Index; Gross National Happiness; Nova Scotia Genuine Progress } \\
\text { Index; OECD Better Life Initiative; Social Institutions and Gender Index; } \\
\text { Sustainable Governance Indicators }\end{array}$ \\
\hline 8 & $\begin{array}{l}\text { Subjective } \\
\text { Well-Being }\end{array}$ & 5 & $\begin{array}{l}\text { Child and Youth Well-Being Index; Gross National Happiness; Happy } \\
\text { Planet Index; Index of Child Well-Being in Europe; OECD Better Life } \\
\text { Initiative }\end{array}$ \\
\hline 9 & Equity & 3 & $\begin{array}{l}\text { Economist Intelligence Unit's QoL Index; Indices of Social Development; } \\
\text { Well-Being of Nations }\end{array}$ \\
\hline 9 & Culture & 3 & $\begin{array}{l}\text { Canadian Index of Well-Being; Gross National Happiness; Well-Being } \\
\text { of Nations }\end{array}$ \\
\hline
\end{tabular}


Table 3. Human Well-Being (HWB) focal areas ranked by the number of indicators in Smith et al. [13].

\begin{tabular}{cc}
\hline Focal area & \# of indicators \\
\hline Health & 112 \\
Living standards & 79 \\
Social cohesion & 68 \\
Education & 67 \\
Safety \& security & 61 \\
Others & 54 \\
\hline
\end{tabular}

\subsection{Focal Areas Relevant for Measuring Human Well-Being in the Conservation Context}

Given the numerous conservation projects globally that impact the well-being of local people, one could conceivably find examples where almost every focal area of HWB in the indices reviewed is relevant. The choice of which focal areas to include when measuring HWB is likely to be specific to a local context. Rather than be prescriptive about which of the 11 focal areas shared by more than one index to use, here we explore the relevance of each focal area to conservation initiatives and note the contexts in which they may be less or more relevant.

The most frequent focal area in the HWB indices reviewed is "living standard", which includes income and wealth. Improving material living standards is often a stated policy goal of international organizations as well as national or local governments, and the ability to provide empirical evidence of how a conservation initiative impacts living standards may be fundamental for an initiative's on-going support. In Kenya, for example, fisheries closures and gear restrictions have led to higher local fish catches, greater income, and more support for fisheries conservation [15]. In certain conservation contexts, such as subsistence livelihoods or non-market activities that expand people's consumption, measuring material living standards may be less relevant. Generally, though, we hypothesize that measuring change in living standards is likely to be relevant for measuring HWB impacts from most conservation initiatives.

Health is one of the most frequently used focal areas in HWB indices, perhaps because health is fundamental to realizing one's well-being potential. Poor health can limit opportunities for benefiting from other elements of HWB such as better living standards or education. Within the conservation context, health may be linked to the provisioning goods and services that nature provides, such as clean water and adequate food [16]. Health may also be linked to the consumption of natural resources such as bush meat and medicinal plants e.g., $[17,18]$ or to disease and the degradation of nature via zoonotic disease transmission [19]. Thus including health as a focal area for measuring HWB may be warranted in many conservation initiatives.

The links between education and conservation may be less direct than for the focal areas above, but changes in the management of natural resources such as fuel wood and water supply may change the opportunity costs for school-aged children tasked with collecting these resources. There is evidence showing a correlation between time spent on collecting fuel wood or water and school attendance [20-22]. Given this link, conservation initiatives that impact the availability of these local natural resources may also impact education. Additionally, conservation initiatives that increase local incomes may result in 
greater local investments in schools and education. Therefore, including education as a focal area for measuring conservation HWB impacts may be relevant to some conservation initiatives.

The capacity of local people to manage their natural resources is often crucial to conservation [23,24], and shared social norms and social capital are known to be a success factor for the self-organized social-ecological systems upon which many rural people depend $[25,26]$. The HWB literature suggests that social connections and relationships are important for an individual's sense of well-being (see [27] for a review). We hypothesize that the HWB focal area of social cohesion is particularly relevant to conservation initiatives in developing countries because the level of social cohesion may correlate with the ability to effectively manage local resources [28,26].

The security focal area is largely about avoiding negative impacts on HWB. The benefits to HWB come from reducing or eliminating vulnerabilities to physical insecurity and economic insecurity that can cause a decline in HWB. In northern Kenya, for example, guards protecting community grasslands also improved local security in villages, and this was cited by local people as of greater value to local HWB than new income-generating activities or school scholarships [29]. We hypothesize that the security focal area is relevant to conservation in contexts where physical violence is prevalent or where a large proportion of the population risks precipitous declines in living standards due to economic insecurities such as being marginally above a poverty line or relying on a single natural resource for their livelihoods.

For the environment focal area, the impact pathway on living standards from a conservation initiative may be more about the volume or biomass of a local natural resource than the variety or biological diversity of the resource [30,31]. This may be especially relevant for subsistence natural resources usage where HWB depends on an adequate supply of the resource such as fish or animal fodder. Environment may also impact HWB via soil erosion and clean water and air. Including the environment as a focal area is likely to be relevant to many conservation initiatives, and measuring changes in the volume or biomass of natural resources upon which people depend may be particularly relevant.

In writing about common-pool resource management, Ostrom notes that collective choice arrangements allowing most resource appropriators to participate in the decision-making process is vital for successful common-pool resource governance [32]. Where local people have a say in how natural resources are governed, resource productivity may improve which can benefit both people and nature e.g., [33,31]. A study comparing different approaches in the governance of marine protected areas found that community-based governance of resources resulted in greater socioeconomic benefits to local people than government-managed national parks [34]. We suggest that measuring changes in governance, such as local levels of conflict and leadership, may be important for understanding changes in HWB from a conservation initiative.

Measuring changes in the work-life balance of local people is relevant to conservation in contexts where initiatives may impact travel time for resource collection such as coastal fisheries or may impact time for tasks such as fuel wood collection. In locations where this is the case, and especially where "time poverty" among women is an issue, including the work-life balance focal area may be relevant. For many conservation initiatives, however, we hypothesize that this focal area may be a lower priority that those above.

Improving a person's subjective well-being may be the ultimate goal of HWB, but it is harder to measure than objective well-being and can vary depending on a number of exogenous factors. Given 
that conservation is only beginning to measure HWB impacts, the challenging measurement of a subjective well-being focal area may be more relevant once basic HWB measurement capacity is in place.

Studies of conservation initiatives have noted a bias towards participation by those who are economically better-off e.g., $[35,36]$ and that project benefits tend to flow to the better-off ("elite capture of benefits") e.g., [37,38]. While an inequitable distribution of benefits may improve HWB for some, inequity may negatively impact social cohesion [39]. Equity is most relevant in community conservation contexts that depend on the support of the community for success. We hypothesize that for community-based conservation, equity is an important attribute to measure. However, we would include indicators on equity within the social cohesion focal area rather than adding it as a stand-alone focal area.

Sacred groves and cultural taboos against fishing in an area or hunting particular wildlife may be perceived by local people as impacting HWB [40,41]. Measuring cultural impacts on HWB may be relevant for conservation initiatives that are built on cultural knowledge or traditions and especially for indigenous and community conserved areas [41]. As with equity above, we suggest that impacts on culture could be measured as part of social cohesion, and a specific focal area may be unnecessary.

\subsection{Existing Indices for Measuring Human Well-Being}

There are benefits to using an existing index for measuring HWB, not the least of which are established methodologies for many indices and the "brand" awareness of the index. Within conservation, there are at least two existing frameworks for measuring HWB. The first builds on a review of the social impacts of protected areas [42] and the second builds on the Millennium Ecosystem Assessment's definition of HWB [43]. Determining what to measure within HWB based on the social impacts of protected areas may bias the results towards protected areas issues and could overlook the body of literature on measuring HWB outside conservation and focal areas such as social cohesion. The Millennium Ecosystem Assessment's definition of HWB is based on the 1997-1998 "Voices of the Poor" studies in 23 countries that asked poor people to "reflect, analyse, and express their ideas of the bad and the good life" [16]. This framework is problematic because it does not include two focal areas - education and the environment - that may be crucial to HWB as it relates to conservation, limiting the utility of using the Millennium Ecosystem Assessment's HWB framework in conservation. Identifying a more suitable HWB framework from among those reviewed here is more likely.

If the focal areas of equity and culture are combined under social cohesion as we suggest above, nine common focal areas remain. Among the list of indices in this review, three include at least eight of the nine focal areas: Bhutan's Gross National Happiness Index (GNHI), the OECD's Better Life Index (BLI), and France's Commission on the Measurement of Economic Performance and Social Progress (CMEPSP). GNHI was created in 2008 specifically to measure Bhutan's social progress, and the focal areas and weightings reflect the country's specific priorities. The BLI was created in 2010 as a tool for developed/industrial countries to measure changes in HWB. The BLI is based on the CMEPSP's report, and the rich documentation the report provides on how to measure HWB regardless of the context. The CMEPSP's 2009 report on measuring HWB was co-authored by several eminent economists (J. Stiglitz, A. Sen and J.P. Fitoussi), and the report includes large contributions by the 
person who helped develop the GNHI (S. Alkire) [44]. Among current HWB indices, CMEPSP is our recommendation for understanding and selecting HWB focal areas that can be used to measure the impacts of conservation initiatives.

\section{Conclusions}

What conservation organizations choose to measure determines how they define success. Using the more common HWB focal areas ensures conservation organizations are measuring the elements of HWB that many people agree are important. It also provides a shared language of what constitutes HWB and presents results in terms readily understood by those outside conservation. Within conservation, it offers the utility of highlighting the key components of HWB, standardizing results to allow for comparisons of costs and benefits across different conservation strategies, and facilitating the efficient allocation of scarce measurement resources.

Using the more common HWB focal areas to measure HWB impacts could also help raise the profile of conservation. The three most common HWB focal areas in the review-living standards, health, and education - align closely with Millennium Development Goals one, two, four, five and six [45]. Measuring HWB with focal areas widely recognized as important by policy makers may help influence the next generation of global development goals and expand the constituency for conservation.

Finally, choosing focal areas is but one step in a process of measuring HWB impacts. Selecting the indicators nested under each focal area is also important, as is a robust research design, data collection, and data analysis. Deciding what to measure is critical but the process of actually measuring elements of HWB is equally important.

\section{Acknowledgments}

We wish to thank Sebastiaan Hess for comments on the draft, and Seth Neiman, Harry and Shirley Hagey of the HRH Foundation, and the Schooner Foundation for providing the funding to make this work possible.

\section{Conflict of Interest}

The authors declare no conflict of interest.

\section{References}

1. Brockington, D.; Igoe, J.; Schmidt-Soltau, K. Conservation, human rights and poverty reduction. Conserv. Biol. 2006, 20, 250-252.

2. West, P.; Igoe, J.; Brockington, D. Parks and peoples: The social impact of protected areas. Annu. Rev. Anthropol. 2006, 35, 251-277.

3. Sunderland, T.C.; Sayer, J.; Hoang, M.H. Evidence-Based Conservation: Lessons from the Lower; Mekong; Routledge: London, UK, 2012.

4. Underwood, A.J. On beyond BACI: Sampling designs that might reliably detect environmental disturbances. Ecol. Appl. 1994, 4, 3-15.

5. Krebs, C.J. Ecological methodology; Addison Wesley Longman: Menlo Park, CA, USA, 1999. 
6. Ferraro, P.J.; Hanauer, M.M.; Sims, K.R. Conditions associated with protected area success in conservation and poverty reduction. Proc. Natl. Acad. Sci. USA 2011, 108, 13913-13918.

7. Naughton-Treves, L.; Alix-Garcia, J.; Chapman, C.A. Lessons about parks and poverty from a decade of forest loss and economic growth around Kibale National Park, Uganda. Proc. Natl. Acad. Sci. USA 2011, 108, 13919-13924.

8. Conservation Measures Partnership. Open Standards for the Practice of Conservation. Available online: http://www.conservationmeasures.org/ (accessed on 14 December 2012).

9. Conservation Initiative on Human Rights. Available online: https://www.community.iucn.org/ cihr/Pages/default.aspx (accessed on 14 December 2012).

10. Roe, D.; Yassin-Mohammed, E.; Porras, I.; Giuliani, A. Linking biodiversity conservation and poverty reduction: De-polarizing the conservation-poverty debate. Conser. Lett. 2012, doi: 10.1111/j.1755-263X.2012.00292.x.

11. World Development Report. Attacking Poverty 2000/2001; World Bank: Washington, DC, USA, 2000.

12. Giovannini, E. A framework to measure the progress of societies. Rev. Econ. Pol. 2011, 121, 93-118.

13. Smith, L.M.; Case, J.L.; Smith, H.M.; Harwell, L.C.; Summers, J.K. Relating ecosystem services to domains of human well-being: Foundation for a US index. Ecol. Indic. 2013, 28, 79-90.

14. Progress Around the World. Available online: http://www.wikiprogress.org (accessed on 14 December 2012).

15. McClanahan, T.R. Effects of fisheries closures and gear restrictions on fishing income in a Kenyan coral reef. Conserv. Biol. 2010, 24, 1519-1528.

16. Millennium Ecosystem Assessment. Ecosystems and Human Well-Being: Current State and Trends; Island Press: Washington, DC, USA, 2005; Volume 1.

17. Golden, C.D.; Fernald, L.C.; Brashares, J.S.; Rasolofoniaina, B.R.; Kremen, C. Benefits of wildlife consumption to child nutrition in a biodiversity hotspot. Proc. Natl. Acad. Sci. USA 2011, 108, 19653-19656.

18. Joshi, P.; Rao, N. Role of indigenous people in conservation of biodiversity of medicinal plants: An Indian case study. Sur. Sustain. 2011, doi:10.1007/978-3-540-95991-5_10.

19. Quammen, D. Spillover: Animal Infections and the Next Human Pandemic; W.W. Norton: New York, NY, USA, 2012.

20. Nankhuni, F.J.; Findeis, J.L. Natural resource-collection work and children's schooling in Malawi. Agr. Econ. 2004, 31, 123-134.

21. Bandyopadhyay, S.; Shyamsundar, P.; Baccini, A. Forests, biomass use and poverty in Malawi. Ecol. Econ. 2011, 70, 2461-2471.

22. Boone, C.; Glick, P.; Sahn, D.E. Household water supply choice and time allocated to water collection: Evidence from Madagascar. J. Dev. Stud. 2011, 47, 1826-1850.

23. Danielsen, F.; Burgess, N.D.; Balmford, A.; Donald, P.F.; Funder, M.; Jones, J.; Alviola, P. Local participation in natural resource monitoring: A characterization of approaches. Conserv. Biol. 2008, 23, 31-42. 
24. Thomas, D.H.L. Local organisations - an entry point for conservation and poverty reduction. In Biodiversity Conservation and Poverty Alleviation: Exploring the Evidence for a Link; Roe, D., Elliott, J., Sandbrook, C., Walpole, M., Eds.; John Wiley \& Sons, Ltd.: Chichester, UK, 2013.

25. Ostrom, E. A general framework for analyzing sustainability of social-ecological systems. Science 2009, 325, 419-422.

26. Gutiérrez, N.L.; Hilborn, R.; Defeo, O. Leadership, social capital and incentives promote successful fisheries. Nature 2011, 470, 386-389.

27. Helliwell, J.F. Understanding and improving the social context of well-being. Nat. Bur. Econ. Res. 2012, No. w18486.

28. Tang, C.P.; Tang, S.Y. Institutional adaptation and community-based conservation of natural resources: The cases of the Tao and Atayal in Taiwan. Hum. Ecol. 2010, 38, 101-111.

29. Glew, L. Evaluating the Effectiveness of Community-Based Conservation in Northern Kenya. Ph.D. Thesis, University of Southampton, Hampshire, UK, 2012.

30. Balmford, A.; Rodrigues, A.S.L.; Walpole, M.; Ten Brink, P.; Kettunen, M. The Economics of Ecosystems and Biodiversity: Scoping the Science; European Commission: Cambridge, UK, 2008.

31. Leisher, C.; Hess, S.; Boucher, T.M.; van Beukering, P.; Sanjayan, M. Measuring the impacts of community-based grasslands management in Mongolia's Gobi. PLoS One 2012, 7, e30991.

32. Ostrom, E. Governing the Commons: The Evolution of Institutions for Collective Action; Cambridge University Press: New York, NY, USA, 1990.

33. Agarwal, B. Gender and forest conservation: The impact of women's participation in community forest governance. Ecol. Econ. 2009, 68, 2785-2799.

34. McClanahan, T.R.; Marnane, M.J.; Cinner, J.E.; Kiene, W.E. A comparison of marine protected areas and alternative approaches to coral-reef management. Curr. Biol. 2006, 16, 1408-1413.

35. Weber, J.G.; Sills, E.O.; Bauch, S.; Pattanayak, S.K. Do ICDPs work? An empirical evaluation of forest-based microenterprises in the Brazilian Amazon. Land Econ. 2011, 87, 661-681.

36. Groom, B.; Grosjean, P.; Kontoleon, A.; Swanson, T.; Zhang, S. Relaxing rural constraints: A "win-win" policy for poverty and environment in China? Oxford Econ. Pap. 2010, 62, 132-156.

37. Jumbe, C.; Angelsen, A. Do the poor benefit from devolution policies? Evidence from Malawi's forest co-management program. Land Econ. 2006, 82, 562-581.

38. Jagger, P. Forest Incomes After Uganda's Forest Sector Reform: Are the Rural Poor Gaining? CAPRi Working Paper No. 92; International Food Policy Research Institute: Washington, DC, USA, 2008.

39. Wilkinson, R.G.; Pickett, K.E. Income inequality and social dysfunction. Annu. Rev. Sociol. 2009, $35,493-511$.

40. Bhagwat, S.; Kushalappa, C.; Williams, P.; Brown, N. The role of informal protected areas in maintaining biodiversity in the Western Ghats of India. Ecol. Soc. 2005, 10, 8.

41. Robson, J.P.; Berkes, F. Sacred nature and community conserved areas. In Nature and Culture: Rebuilding Lost Connections; Pilgrim, S., Pretty, J., Eds.; Routledge: London, UK, 2012.

42. Stephanson, S.; Mascia, M. Measuring Social Well-Being: An Approach to Spatially Assess the Social Context for Large-Scale Conservation Planning and Action; World Wildlife Fund: Washington, DC, USA, 2009. 
43. Kittinger, J.N.; Finkbeiner, E.M.; Glazier, E.W.; Crowder, L.B. Human dimensions of coral reef social-ecological systems. Ecol. Soc. 2012, 17, 17.

44. Stiglitz, J.E.; Sen, A.; Fitoussi, J.P. Report by the Commission on the Measurement of Economic Performance and Social Progress. Available online: www.stiglitz-sen-fitoussi.fr/ (accessed on 14 December 2012).

45. MDGs. United Nations Millennium Declaration: Resolution Adopted by the General Assembly; United Nations: New York, NY, USA, 2000.

(C) 2013 by the authors; licensee MDPI, Basel, Switzerland. This article is an open access article distributed under the terms and conditions of the Creative Commons Attribution license (http://creativecommons.org/licenses/by/3.0/). 